\title{
Grain sorghum nitrogen use as affected by planting practice and nitrogen rate
}

\author{
${ }^{1}$ Department of Agroforestry, Kwame Nkrumah University of Science and Technology, Ghana. ${ }^{2}$ Department of \\ Agronomy and Horticulture, University of Nebraska, Lincoln, USA. *Corresponding author: akwasi_abun- \\ yewa@yahoo.com
}

Akwasi A. Abunyewa $^{1 *}$, Richard B. Ferguson ${ }^{2}$, Charles S. Wortmann ${ }^{2}$, Stephen C. Mason ${ }^{2}$

\begin{abstract}
Water and nitrogen supply are often the most critical factors limiting growth and yield in crop production. A study was carried out in 2006 and 2007 to determine N use efficiency of grain sorghum (Sorghum bicolor (L.) Moench) in dryland production at the University of Nebraska, Lincoln, Nebraska, South Central Agricultural Laboratory. The study evaluated three row planting arrangements (RPA) including all rows planted (s0), alternate rows planted (s1), and two rows planted alternated with two skipped rows (s2) in a complete factorial with plant populations (PP) of 75,000 and 150,000 plants ha- 1 and $\mathrm{N}$ application rates of 0,50,100, and $150 \mathrm{~kg} \mathrm{~N}$ $\mathrm{ha}^{-1}$. The objectives of the study were to determine the optimum $\mathrm{N}$ rate, magnitude of $\mathrm{N}$ uptake, and $\mathrm{N}$ use efficiency (NUE) for grain sorghum under dryland conditions with different row configurations. Conventional planting out-yielded skip-row planting by 23 to $36 \%$ in each year. Percent $\mathrm{N}$ translocated from biomass to grain at physiological maturity at half bloom ranged from 29 to $35 \%$ in 2006 compared with 46 to $51 \%$ in 2007 . The RPA x PP interaction affected internal NUE (IEN) in 2006 and 2007, and physiological NUE (PEN) in 2006. The RPA x N rate interaction affected partial factor productivity (PFPN) in 2006.
\end{abstract}

Keywords: Agronomic, grain sorghum, nitrogen use efficiency, productivity. 


\section{Introduction}

Grain sorghum is tolerant of soil water deficits and efficient in soil nutrient uptake due to its fibrous root system. However, sorghum yield potential can be substantially reduced when water and $\mathrm{N}$ are limited. $\mathrm{Ni}$ trogen uptake by sorghum is affected by several factors including $\mathrm{N}$ availability, soil water availability, soil organic matter, soil chemical and physical properties, previous crop, and genotype (Wortmann et al., 2007; Gardner et al., 1994).

Sorghum is typically grown under dryland conditions and soil water deficits increase the risk of yield loss potential and limits yield response to fertilizer application. Nitrogen deficiencies can reduce water use efficiency due to reduced yield potential and greater soil evaporation (Fisher and Turner, 1979). In highly variable environments inherent to dryland cropping systems, variable $\mathrm{N}$ mineralization from soil organic matter and crop residues challenges prediction of an optimal $\mathrm{N}$ application rate (Schlegel et al., 2005).

Nitrogen fertilizer recommendations for conventional planting in Nebraska are based on yield goals, soil organic matter level, and residual soil nitrate-N (Shapiro et al., 2009). To improve soil water availability and avoid water stress, skip-row configurations have been used elsewhere with success (Routley et al., 2003; Abunyewa et al., 2010; Abunyewa et al., 2011). Different row configurations may influence plant canopy architecture, root distribution, $\mathrm{N}$ and water availability, uptake and utilization (Routley et al., 2006).

A key component in crop production is to achieve the greatest ratio of harvested dry weight to water and/or $\mathrm{N}$ use, referred to as water use efficiency (WUE) and $\mathrm{N}$ use efficiency (NUE). Nitrogen use efficiency has several components such as recovery and agronomic efficiency (Dobermann 2005; Mosier et al., 2004; Cassman et al., 2002). Improving NUE is important to reduce the cost of producing a crop since $\mathrm{N}$ is a costly crop production input.

The objectives of this study were to evaluate the effects of row planting arrangement, $\mathrm{N}$ rate and plant population on sorghum grain yield and $\mathrm{N}$ use efficiency in a rain-fed environment.

\section{Materials and Methods}

The study was conducted in 2006 and 2007 at the University of Nebraska-Lincoln, South Central Agricultural Laboratory (SCAL) near Clay Center, Nebraska (lat.40o34'N; long 98o08; $543 \mathrm{~m}$ elevation). The study evaluated three row planting arrangements and two plant populations with different $\mathrm{N}$ rates arranged as a randomized complete block design with four replications. Row planting arrangement (RPA) included the common practice of all rows planted with $76-\mathrm{cm}$ row spacing ( $\mathrm{s} 0$ ) and two skip row configurations: one row planted alternated with one row skipped (s1), and two rows planted alternated with two rows skipped (s2). Each year, sorghum was sown at a site planted to corn in the previous year.

Plots were seeded and thinned after emergence to the final populations of 75,000 and 150,000 plants ha ${ }^{-1}$. During each year a medium (110 days) maturing grain sorghum cv. Dekalb 42-20 (Monsanto Co., USA) was planted at different sites but on the same soil series: Crete silt loam - fine, smectitic, mesic Pachic Arguistolls (USDA Natural Resources Conservation Service). Nitrogen was applied at rates equivalent to 0 , 50,100 and $150 \mathrm{~kg} \mathrm{~N} \mathrm{ha}^{-1}$ as urea in both years. A basal rate of $\mathrm{P}$ equivalent to $40 \mathrm{~kg} \mathrm{ha}^{-1}$ was applied as triple super phosphate to all plots.

Weeds were controlled with pre-emergence herbicides and post-emergence herbicide eight weeks after 
planting at labelled rates using a tractor-mounted boom sprayer. Hand-weeding was also done as necessary throughout the growing seasons to reduce weed pressure.

In-season precipitation, reference evapotranspiration with alfalfa (ETR), solar radiation, wind speed, air temperature and relative humidity during the growing season and 20-year average weather data were obtained from the University of Nebraska Automated Weather Data Network (AWDN) at the site. Canopy temperature and relative humidity were measured with HOBO H8 Pro Series sensors (Version 4.3, Onset Computer Co. 2002. Bourne, MA).

Plots were machine harvested and grain yield determined from $18.2 \mathrm{~m}^{2}$ (3.04 by $6 \mathrm{~m}$ ) in the center of plots of the $\mathrm{s} 0$ and from $9.1 \mathrm{~m}^{2}(1.52$ by $6 \mathrm{~m})$ in the center of plots of the skip-row configurations. Yields were adjusted to $135 \mathrm{~g} \mathrm{~kg}^{-1}$ water concentration by drying a grain subsample at $65{ }^{\circ} \mathrm{C}$ over $72 \mathrm{~h}$ for dry matter determination. Oven-dried sub-samples of stover and grain were analyzed for $\mathrm{N}$ concentration. Stover and grain $\mathrm{N}$ uptake were calculated by multiplying the dry weight of stover and grain by the $\mathrm{N}$ concentration.

Five components of NUE (Cassman et al., 2002; Baligar et al., 2001) were calculated:

i. Partial factor of productivity for $\mathrm{N}$ fertilizer $\left(\mathrm{PFP}_{\mathrm{N}}\right)$, defined as grain yield $(\mathrm{Yg})$ per unit $\mathrm{N}$ applied $\mathrm{PFP}_{\mathrm{N}}=\mathrm{YgNr}^{*} \mathrm{Nr}^{-1}$,

where: $\mathrm{Nr}$ is nitrogen applied at a particular rate

ii. Agronomic $\mathrm{N}$ use efficiency $\left(\mathrm{AE}_{\mathrm{N}}\right)$ also referred to as yield efficiency, defined as the increase in dry matter yield due to $\mathrm{N}$ application.

$\mathrm{AE}_{\mathrm{N}}=(\mathrm{YdNr}-\mathrm{YdN} 0) * \mathrm{Nr}^{-1}$,

where $\mathrm{Yd}$ is dry matter yield and

$\mathrm{N} 0$ is zero $\mathrm{N}$ application

iii. Crop internal efficiency $\left(\mathrm{IE}_{\mathrm{N}}\right)$, defined as grain yield ( $\mathrm{Yg}$ ) over total $\mathrm{N}$ uptake $(\mathrm{Nu})$ in the above ground biomass at physiological maturity
$\mathrm{IE}_{\mathrm{N}}=\mathrm{YgNr} *(\mathrm{NuNr})^{-1}$,

iv. Physiological efficiency $\left(\mathrm{PE}_{\mathrm{N}}\right)$, defined as change in grain yield per unit change in $\mathrm{N}$ accumulation or $\mathrm{N}$ uptake (Nupt) in above ground biomass $\mathrm{PE}_{\mathrm{N}}$ $=(\mathrm{YgNr}-\mathrm{YgN} 0) *(\mathrm{NuNr}-\mathrm{NuN0})^{-1}$,

v. Fertilizer $\mathrm{N}$ recovery efficiency $\left(\mathrm{RE}_{\mathrm{N}}\right)$, also referred to as NUE (Ortega et al., 2016) in above ground biomass at physiological maturity is defined as change in $\mathrm{N}$ uptake per unit $\mathrm{N}$ applied $\mathrm{RE}_{\mathrm{N}}=(\mathrm{NuNr}-\mathrm{NuN} 0) * \mathrm{Nr}^{-1}$.

\section{Statistical analyses}

Statistical analyses were performed using PROC MIXED procedure of SAS 9.1 (SAS Institute, 2007). Planting arrangement and $\mathrm{N}$ rates were treated as fixed effects, and replication was treated as a random effect. Fisher's protected LSD test was used to separate treatment means at $\mathrm{P} \leq 0.05$.

\section{Results}

\subsection{Initial soil analysis}

In all three years, the mean soil bulk density was 1.15 $\mathrm{g} \mathrm{cm}-3$ in the top 0 to $300 \mathrm{~mm}$ depth and $1.24 \mathrm{~g} \mathrm{~cm}^{-3}$ in the 600 to $1200 \mathrm{~mm}$ depth. The soil at the 2006 site had lower nitrate $\left(1.26 \mathrm{mg} \mathrm{kg}^{-1}\right)$ than that of 2007 site ( $\left.4.80 \mathrm{mg} \mathrm{kg}^{-1}\right)$ but higher zinc at 2006 site $\left(1.60 \mathrm{mg} \mathrm{kg}^{-1}\right)$ than that of $2007\left(0.34 \mathrm{mg} \mathrm{kg}^{-1}\right)$, while the remaining measured parameters such as organic matter, available phosphorus and exchangeable potassium were similar.

\subsection{Effects of climate, in-season precipitation and reference evapotranspiration}

During the study period, mean weather conditions were similar to the 20-year average. The excess of evapotranspiration (ET) over precipitation, referred to 
as climatic deficit (Olufayo et al., 1996) was higher in $2006(-207 \mathrm{~mm})$ and $2007(-164 \mathrm{~mm})$ at vegetative stage than $-106 \mathrm{~mm}$ and $-107 \mathrm{~mm}$ half bloom stage, for 2006 and 2007, respectively.

\subsection{Stover and grain yield}

Mean stover yield over $\mathrm{N}$ rate was 15.5 and $13.7 \mathrm{Mg}$ $\mathrm{ha}^{-1}$ in 2006 and 2007, respectively, and mean grain yields over $\mathrm{N}$ rate was 9.2 and $10.6 \mathrm{Mg} \mathrm{ha}^{-1}$ in 2006
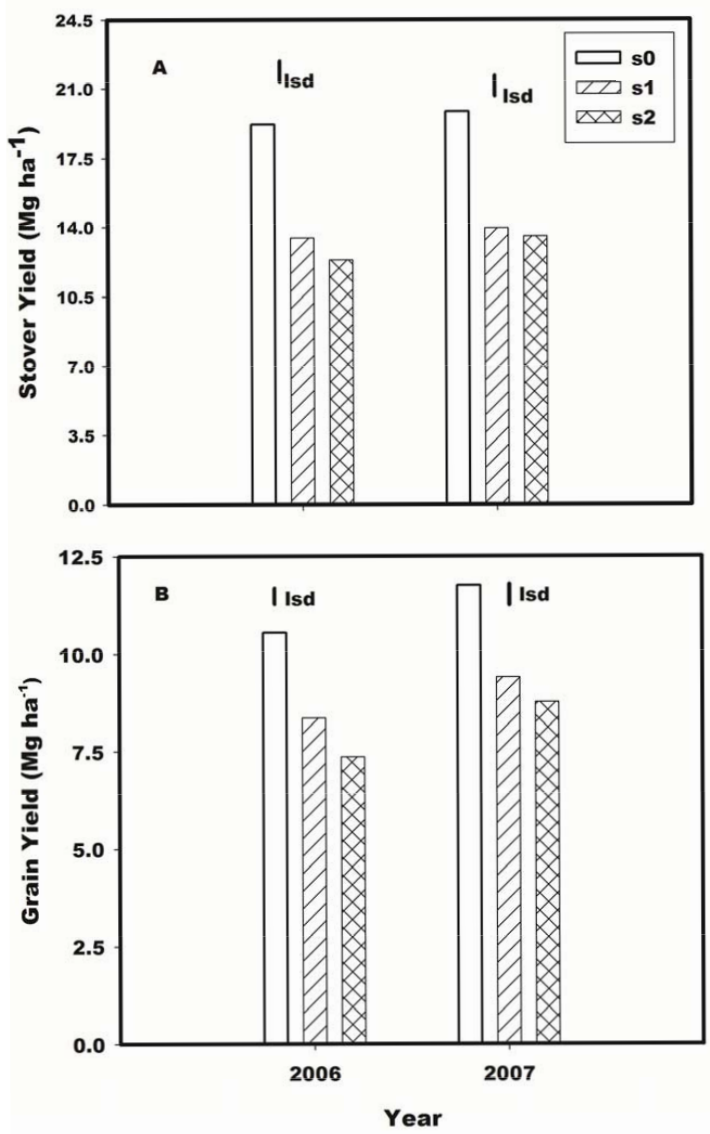

Figure 1. Effect of three row planting arrangement on stover (A) and grain (B) yield at physiological maturity in south-central Nebraska, 2006 and 2007. s0 = conventional planting with all rows planted, $\mathrm{s} 1=$ alternate rows planted, $\mathrm{s} 2=$ two rows planted alternate with two rows skipped. Y-bars $=\mathrm{LSD}(0.05)$. and 2007, respectively. Stover yield at physiological maturity was not affected by the interaction between row planting arrangement (RPA) and plant population (PP). However, interactions between RPA and N rate affected grain yield in both 2006 and 2007.

Stover and grain yield averaged across $\mathrm{N}$ rate were affected by RPA in all years. Conventional row planting out-yielded skip-row planting in stover and grain in all the years. Grain yield was higher with s1 compared with s2 in all years (Figure 1). Nitrogen application increased grain yield in 2006 and 2007 and stover yield in 2006 and 2007 with s0 (Figure 2). The effects of PP on stover and grain yield at physiological maturity were not consistent. However, stover yield was less responsive to $\mathrm{N}$ application in both years with coefficients of determination ranging from 0.57 to 0.99 (Figures 2A and B). The regression equations were not significant for stover yield in both 2006 and 2007.

Grain yield response to $\mathrm{N}$ application was higher in 2007 than 2006. Increased N rate with s0 configuration resulted in increased grain yield in both years. With skip-row configurations, $\mathrm{N}$ application resulted in higher grain yield, though increasing $\mathrm{N}$ rate above $50 \mathrm{~kg} \mathrm{~N} \mathrm{ha}{ }^{-1}$ did not bring corresponding grain yield increase (Figures $2 \mathrm{C}$ and $\mathrm{D}$ ). Increasing $\mathrm{N}$ rate resulted in a quadratic increase in grain yield with a peak at $150 \mathrm{~kg} \mathrm{~N} \mathrm{ha}^{-1}$ with s0 for the two years with $\mathrm{R}^{2}$ values of 0.90 to 0.99 (Figures $2 \mathrm{C}$ and D).

\subsection{Nitrogen concentration, uptake and use effi-} ciency

Stover and grain $\mathrm{N}$ concentration at physiological maturity were not affected by the 2- and 3-way interactions of RPA, PP and $\mathrm{N}$ rate in 
2006 and 2007 (Tables 1 and 2). The RPA x N rate interaction significantly affected grain $\mathrm{N}$ uptake in
2007 due to increased $\mathrm{N}$ uptake of $15 \%$ for s0 and $9 \%$ for s1 and s2 with $\mathrm{N}$ application.

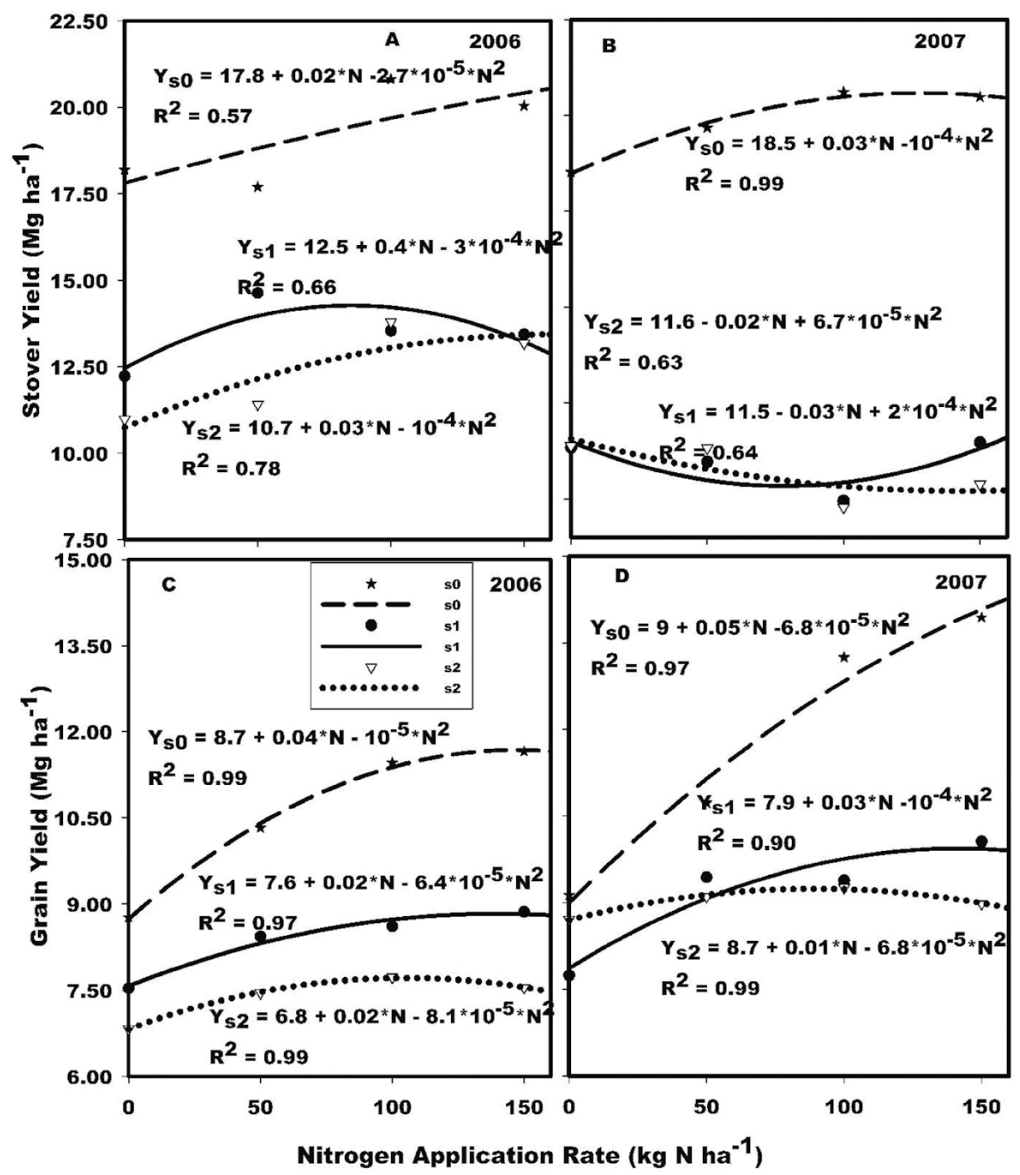

Figure 2. The effect of $\mathrm{N}$ application and planting configuration on stover (A and B) and grain yield (C and D) at physiological maturity in south-central Nebraska in 2006 and 2007. $\mathrm{Y}=$ yield, $\mathrm{s} 0=$ conventional planting with all rows planted, $\mathrm{s} 1=$ alternate rows planted, $\mathrm{s} 2$ = two rows planted alternate with two rows skipped.

The RPA x PP interaction affected $\mathrm{IE}_{\mathrm{N}}$ in 2006 and 2007 and $\mathrm{PE}_{\mathrm{N}}$ in 2006 (Tables 1 and 2). Doubling PP with s0 and s2 increased $\mathrm{IE}_{\mathrm{N}}$ in 2006 and 2007 by 19 and $20 \%$, respectively (Figures $3 \mathrm{~A}$ and B). The RPA $\mathrm{x} P \mathrm{P}$ interaction affected $\mathrm{PE}_{\mathrm{N}}$ but inconsistently over years, and mean $\mathrm{PE}_{\mathrm{N}}$ was higher with $\mathrm{s} 0$ than with skip row planting (Figures $3 \mathrm{C}$ and $\mathrm{D}$ ). The $\mathrm{N}$ rate $\mathrm{x}$ RPA interaction affected $\mathrm{PFP}_{\mathrm{N}}$ in 2006. With each RPA, increasing $\mathrm{N}$ rate from 50 to 100 and finally to $150 \mathrm{~kg} \mathrm{ha}^{-1} \mathrm{~N}$ resulted in 44 to $67 \%$ lower $\mathrm{PFP}_{\mathrm{N}}$. 
Table 1. Analysis of variance summary for grain sorghum with three row planting arrangement, two plant populations and four $\mathrm{N}$ rates in 2006 in south-central Nebraska.

\begin{tabular}{|c|c|c|c|c|c|c|c|c|c|c|}
\hline & \multicolumn{2}{|c|}{$\mathrm{N}$ Concentration $\left(\mathrm{mg} \mathrm{kg}^{-1}\right)$} & $\begin{array}{l}\text { Grain } \\
\left.\text { on ( } \mathrm{mg} \mathrm{kg}^{-1}\right)\end{array}$ & \multicolumn{6}{|c|}{---N Uptake $\left(\mathrm{kg} \mathrm{ha}^{-1}\right)$} & IEN \\
\hline & \multicolumn{5}{|l|}{ DF } & \multicolumn{5}{|c|}{ Mean Square- } \\
\hline-- & & & & & & & & & & \\
\hline RPA & 2 & $0.438 * *$ & $0.594 * *$ & $6867^{* *}$ & $357.1 \mathrm{~ns}$ & $7853^{* * *}$ & $3318 * *$ & $0.0262 \mathrm{~ns}$ & $5244 * *$ & $298.7^{* *}$ \\
\hline PP & 1 & $0.763 * *$ & $0.171 * *$ & $3371 * *$ & $841.7 \mathrm{~ns}$ & $296.4 \mathrm{~ns}$ & $1131 \mathrm{~ns}$ & $0.0043 \mathrm{~ns}$ & $15.65 \mathrm{~ns}$ & $687.4 \mathrm{~ns}$ \\
\hline $\mathrm{N}$ & 3 & $0.199 \mathrm{~ns}$ & $0.035 \mathrm{~ns}$ & $2994 * *$ & $432.5 \mathrm{~ns}$ & $61224 * *$ & $2780 * *$ & $0.0030 \mathrm{~ns}$ & $591.2 \mathrm{~ns}$ & $341.7 \mathrm{~ns}$ \\
\hline RPA $x$ PP & 2 & $0.092 \mathrm{~ns}$ & $0.016 \mathrm{~ns}$ & $328.2 \mathrm{~ns}$ & $101.4 \mathrm{~ns}$ & $160.8 \mathrm{~ns}$ & $98.41 \mathrm{~ns}$ & $0.0010 \mathrm{~ns}$ & $1611^{* *}$ & $180.1^{*}$ \\
\hline $\mathrm{RPA} \times \mathrm{N}$ & 6 & $0.172 \mathrm{~ns}$ & $0.039 \mathrm{~ns}$ & $200.9 \mathrm{~ns}$ & $687.3 \mathrm{~ns}$ & $365.1^{*}$ & $653.2 \mathrm{~ns}$ & $0.0313 \mathrm{~ns}$ & $124.0 \mathrm{~ns}$ & $68.08 \mathrm{~ns}$ \\
\hline$N \times P P$ & 3 & $0.134 \mathrm{~ns}$ & $0.034 \mathrm{~ns}$ & $89.98 \mathrm{~ns}$ & $31.8 \mathrm{~ns}$ & $193.7 \mathrm{~ns}$ & $402.6 \mathrm{~ns}$ & $0.0152 \mathrm{~ns}$ & $348.7 \mathrm{~ns}$ & $35.68 \mathrm{~ns}$ \\
\hline RPA $x P P x N$ & 6 & $0.014 \mathrm{~ns}$ & $0.029 \mathrm{~ns}$ & $249.4 \mathrm{~ns}$ & $544.4 \mathrm{~ns}$ & $66.75 \mathrm{~ns}$ & $562.4 \mathrm{~ns}$ & $0.0076 \mathrm{~ns}$ & $96.64 \mathrm{~ns}$ & $9.97 \mathrm{~ns}$ \\
\hline Residual & 46 & 0.095 & 0.030 & 278.0 & 290.8 & 96.46 & 357.8 & 0.0177 & 423.5 & 48.30 \\
\hline
\end{tabular}

$*=\mathrm{P} \leq 0.05 ; * *=\mathrm{P} \leq 0.01 ; \mathrm{ns}=$ Not significant

Table 2. Analysis of variance summary for effects of row planting arrangement (RPA), plant population (PP), and $\mathrm{N}$ rates on grain sorghum in 2007 in south-central Nebraska

\begin{tabular}{|c|c|c|c|c|c|c|c|c|c|c|}
\hline & & Stover & Grain & Stover & Grain & $\mathrm{PFP}_{\mathrm{N}}$ & $\mathrm{AE}_{\mathrm{N}}$ & $\mathrm{RE}_{\mathrm{N}}$ & $\mathrm{PE}_{\mathrm{N}}$ & $\mathrm{IE}_{\mathrm{N}}$ \\
\hline & \multicolumn{10}{|c|}{ N Concentration $\left(\mathrm{mg} \mathrm{kg}^{-1}\right)$} \\
\hline & \multicolumn{5}{|l|}{$\mathrm{DF}$} & \multicolumn{5}{|c|}{ _Mean Square------------------------------------------------------- } \\
\hline RPA & 2 & $1.053^{* *}$ & $11.35^{* *}$ & $21565^{* *}$ & $740.9 \mathrm{~ns}$ & $9120.1 * *$ & $9030 * *$ & $0.0937^{*}$ & $4854^{*}$ & $39.2 \mathrm{~ns}$ \\
\hline PP & 1 & $2.868 * *$ & $0.72 *$ & $24646 * *$ & $5680 * *$ & $36.56 \mathrm{~ns}$ & $91.81 \mathrm{~ns}$ & $0.0037 \mathrm{~ns}$ & $179 \mathrm{~ns}$ & $1107 * *$ \\
\hline $\mathrm{N}$ & 3 & $0.130 \mathrm{~ns}$ & $7.2 *$ & $2598.6^{*}$ & $4967 * *$ & $97577 * *$ & $6280 * *$ & $0.0949 *$ & $3564 \mathrm{~ns}$ & $50.69 \mathrm{~ns}$ \\
\hline RPA x PP & 2 & $0.117 \mathrm{~ns}$ & $0.08 \mathrm{~ns}$ & $558.6 \mathrm{~ns}$ & $265.1 \mathrm{~ns}$ & $81.12 \mathrm{~ns}$ & $1364 \mathrm{~ns}$ & $0.0166 \mathrm{~ns}$ & $3849 \mathrm{~ns}$ & $208.2 * *$ \\
\hline RPA $\times N$ & 6 & $0.112 \mathrm{~ns}$ & $0.05 \mathrm{~ns}$ & $178.2 \mathrm{~ns}$ & $1576.4^{*}$ & $124.9 \mathrm{~ns}$ & $169.9 \mathrm{~ns}$ & $0.0145 \mathrm{~ns}$ & $432.4 \mathrm{~ns}$ & $44.17 \mathrm{~ns}$ \\
\hline $\mathrm{N} \times \mathrm{PP}$ & 3 & $0,028 \mathrm{~ns}$ & $0.01 \mathrm{~ns}$ & $142.7 \mathrm{~ns}$ & $59.4 \mathrm{~ns}$ & $92.28 \mathrm{~ns}$ & $962.5 \mathrm{~ns}$ & $0.0009 \mathrm{~ns}$ & $1001 \mathrm{~ns}$ & $28.54 \mathrm{~ns}$ \\
\hline RPA $x$ PP $x N$ & 6 & $0.024 \mathrm{~ns}$ & $0.21 \mathrm{~ns}$ & $264.4 \mathrm{~ns}$ & $1216.4 \mathrm{~ns}$ & $416.3 n s$ & $100.9 \mathrm{~ns}$ & $0.0125 \mathrm{~ns}$ & 1073.ns & $17.61 \mathrm{~ns}$ \\
\hline Residual & 4 & 0.096 & 0.15 & 711.2 & 569.6 & 195.2 & 1234.1 & 0.0209 & 1433.6 & 36.41 \\
\hline
\end{tabular}

$$
*=\mathrm{P} \leq 0.05 ; * *=\mathrm{P} \leq 0.01 ; \mathrm{ns}=\text { Not significant }
$$

Compared to the zero $\mathrm{N}$ treatment, increased $\mathrm{N}$ rate resulted in increased plant $\mathrm{N}$ concentration in 2006 by up to $18 \%$ and increased grain $\mathrm{N}$ concentration in 2007 by up to $12 \%$ (Table 3). Application of $\mathrm{N}$ resulted in up to 30 and $22 \%$ more stover $\mathrm{N}$ uptake in 2006 and 2007, respectively, and up to $30 \%$ more grain $\mathrm{N}$ uptake in 2007 (Table 3).

Averaged over $\mathrm{N}$ rates, $\mathrm{s} 0$ had higher $\mathrm{PFP}_{\mathrm{N}}, \mathrm{AE}_{\mathrm{N}}$ and $\mathrm{PE}_{\mathrm{N}}$ than s1 and s2 in 2006 and 2007 (Figures $4 \mathrm{~A}$, $\mathrm{B}$ and $\mathrm{C}$ ). Conventional row planting ( $\mathrm{s} 0$ ) had higher $\mathrm{IE}_{\mathrm{N}}$ and $\mathrm{RE}_{\mathrm{N}}$ only in 2007 (Figures $4 \mathrm{D}$ and E). Generally, s1 had higher or equal NUE compared with 
s2 (Figure 4). Averaged over RPA, $50 \mathrm{~kg} \mathrm{ha}^{-1} \mathrm{~N}$ had higher $\mathrm{PFP}_{\mathrm{N}}$ and $\mathrm{AE}_{\mathrm{N}}$ than with higher $\mathrm{N}$ rates in both 2006 and 2007 (Figures $5 \mathrm{~A}$ and B). No N appli cation and/or $50 \mathrm{~kg} \mathrm{ha}^{-1} \mathrm{~N}$ had higher REN in 2007 (Figure 5D) and higher $\mathrm{IE}_{\mathrm{N}}$ in 2006 compared with 100 and $150 \mathrm{~kg} \mathrm{ha}^{-1} \mathrm{~N}$ (Figure 5E).
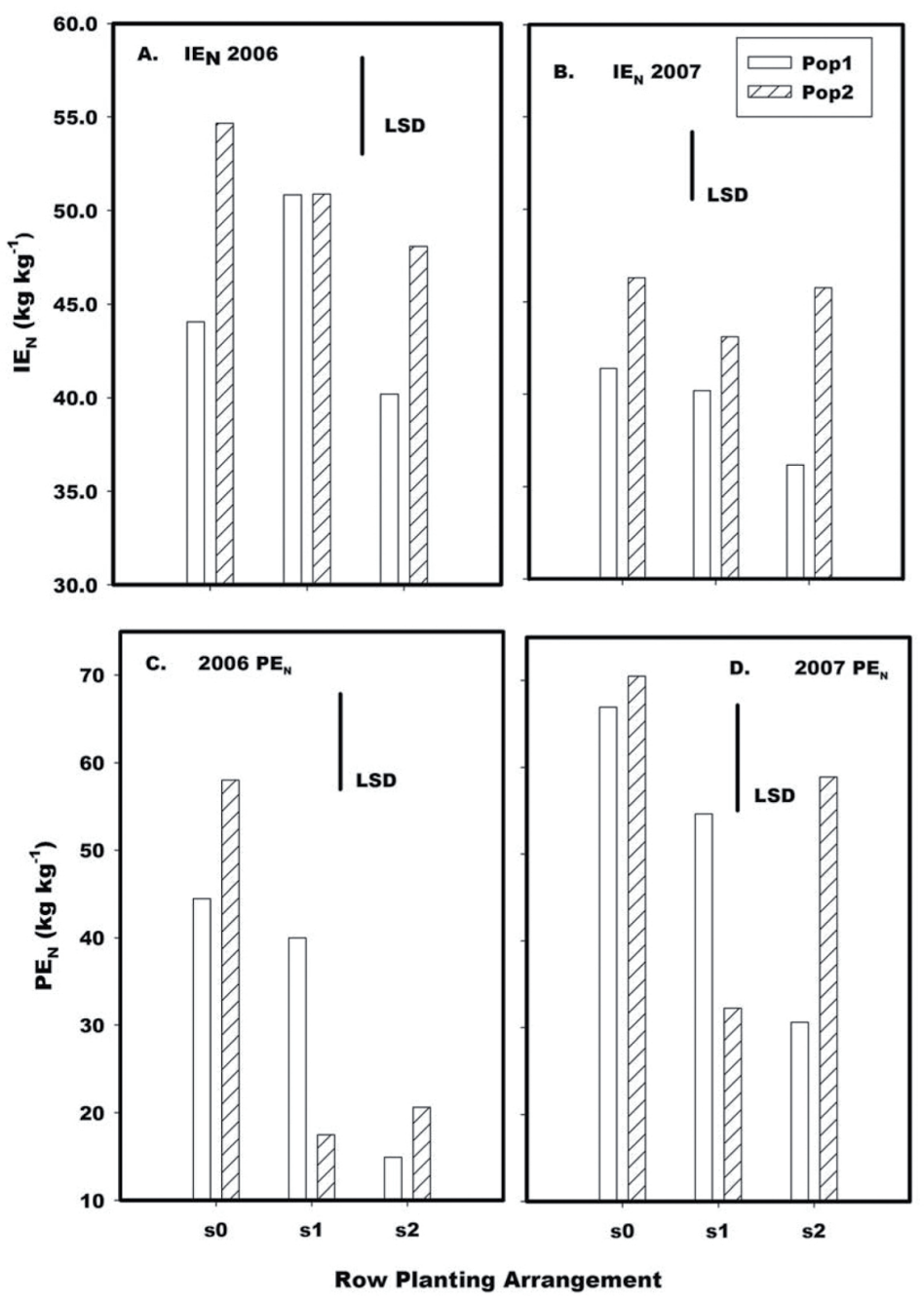

Figure 3. Effect of plant population x row planting arrangement interaction on $\mathrm{IE}_{\mathrm{N}}$ in 2006 and 2007 (A and $\mathrm{B}$ ), and $\mathrm{PE}_{\mathrm{N}}$ in 2006 and 2007 (C and D) in south-central Nebraska. s0 = conventional planting with all rows planted, $\mathrm{s} 1=$ alternate rows planted, $\mathrm{s} 2=$ two rows planted alternate with two rows skipped. PP1 $=75,000$ and PP2 $=$ 150,000. Y-bars $=\operatorname{LSD}(0.05)$ within site-year. 
Table 3. Effect of $\mathrm{N}$ application rates on $\mathrm{N}$ concentration, uptake, and use efficiency in grain sorghum in 2006 and 2007 in south-central Nebraska.

\begin{tabular}{|c|c|c|c|c|c|c|c|c|}
\hline \multirow[b]{3}{*}{$\mathrm{N}\left(\mathrm{kg} \mathrm{ha}^{-1}\right)$} & \multicolumn{4}{|c|}{ - } & \multicolumn{4}{|c|}{ 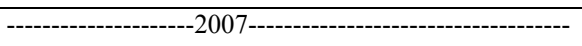 } \\
\hline & Stover & Grain & Stover & Grain & Stover & Grain & Stover & Grain \\
\hline & \multicolumn{2}{|c|}{$\mathrm{N}$ concentration $\left(\mathrm{mg} \mathrm{kg}^{-1}\right)$} & \multicolumn{2}{|c|}{----N uptake $\left(\mathrm{kg} \mathrm{ha}^{-1}\right)-$} & \multicolumn{4}{|c|}{--N concentration $\left(\mathrm{mg} \mathrm{kg}^{-1}\right)------\mathrm{N}$ uptake $\left(\mathrm{kg} \mathrm{ha}^{-1}\right)-$} \\
\hline 0 & 6.25 & 10.65 & 67.5 & 90.2 & 7.41 & 14.36 & 84.9 & 122.3 \\
\hline 50 & 6.17 & 13.06 & 76.9 & 100.6 & 7.33 & 15.26 & 97.5 & 147.9 \\
\hline 100 & 6.45 & 11.53 & 89.8 & 105.7 & 7.68 & 15.81 & 103.5 & 164.5 \\
\hline 150 & 6.70 & 13.29 & 96.3 & 121.6 & 7.83 & 16.35 & 109.2 & 174.6 \\
\hline$P$ value & 0.114 & 0.706 & 0.001 & 0.453 & 0.264 & 0.001 & 0.016 & 0.001 \\
\hline LSD & 0.652 & 4.470 & 11.12 & 33.37 & 0.566 & 0.642 & 13.23 & 12.11 \\
\hline
\end{tabular}

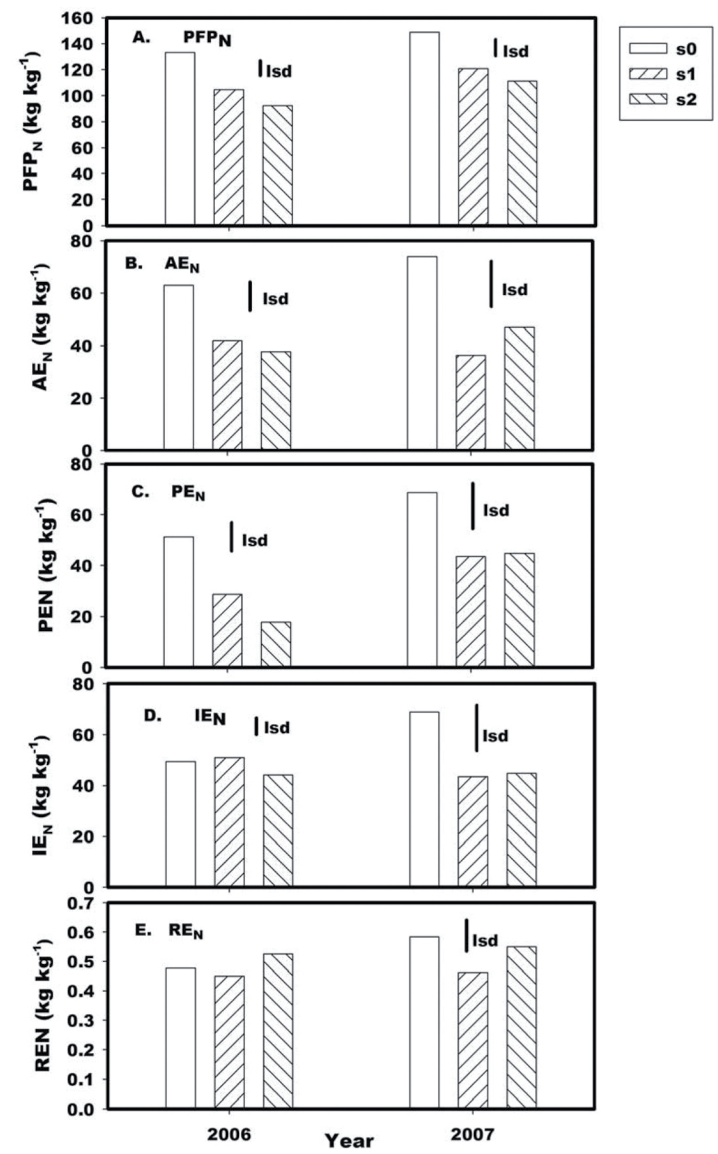

Figure 4. Effect of row planting arrangement on $\operatorname{PFP}_{N \mathrm{~N}}(\mathrm{~A}) \mathrm{AE}_{\mathrm{N}}(\mathrm{B}), \mathrm{PE}_{\mathrm{N}}(\mathrm{C}), \mathrm{IE}_{\mathrm{N}}(\mathrm{D})$ and $\mathrm{RE}_{\mathrm{N}}(\mathrm{E})$ in 2006 and 2007 in southcentral Nebraska. $\mathrm{s} 0=$ conventional planting with all rows planted, $\mathrm{s} 1=$ alternate rows planted, $\mathrm{s} 2=$ two rows planted alternate with two rows skipped. Y-bars $=$ LSD 0.05 within site-year 


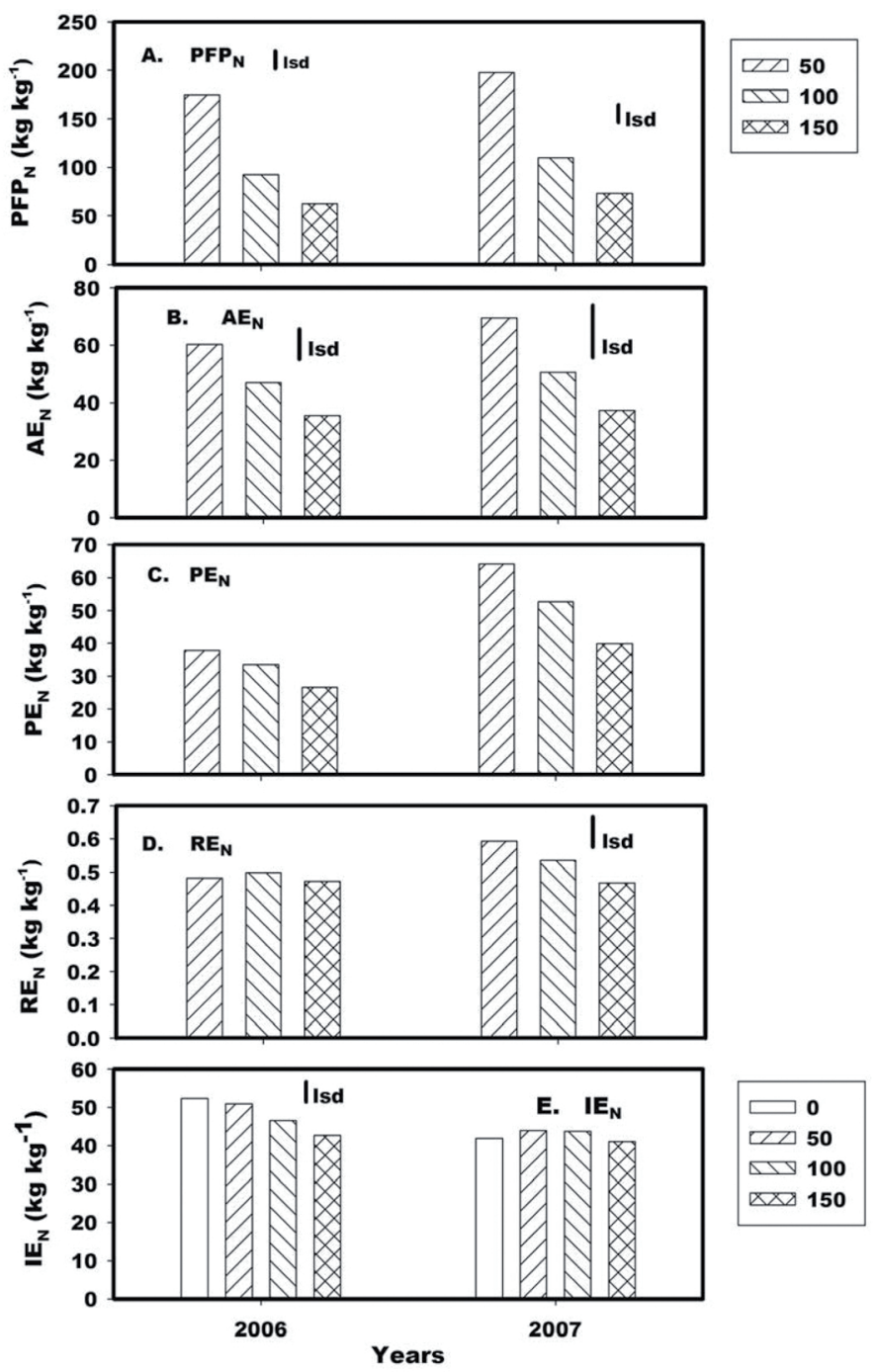

Figure 5. Effect of $N$ application rate $\left(0,50,100\right.$ and $\left.150 \mathrm{~kg} \mathrm{~N}^{-1}\right)$ on $\operatorname{PFP}_{N}(A), \mathrm{AE}_{\mathrm{N}}(\mathrm{B}), \mathrm{PE}_{\mathrm{N}}(\mathrm{C}), \mathrm{RE}_{\mathrm{N}}(\mathrm{D})$ and $\mathrm{IE}_{\mathrm{N}}(\mathrm{E})$ in 2006 and 2007 in south-central Nebraska. Y-bars = LSD (0.05) within site-year

\section{Discussion}

According to Stone et al., (1996), water deficit at half bloom stage of grain sorghum will affect grain yield more than water deficit in the vegetative or grain fill stages. The relatively high climatic deficit observed at vegetative and half bloom stages could be attributed to low in-season precipitation and uneven distribution of rainfall events. Sorghum was planted each year when soil water was adequate to ensure good plant establishment. The stired soil water met evaporative 
demands, thus eliminating any adverse effect of soil water deficit at the half bloom stage. Moreover, moderately dry periods may not affect grain yield since sorghum is noted for its ability to withstand dry conditions (Shackel and Hall, 1984). Initial stored soil water and in-season precipitation supported high biomass production with $\mathrm{s} 0$ resulting in greater grain yield compared to both s1 and s2 (Abunyewa et al., 2010; Abunyewa et al., 2011).

The low response to higher $\mathrm{N}$ (above $50 \mathrm{~kg} \mathrm{~N} / \mathrm{ha}$ ) with the skip row configuration agrees with other research findings that in high yielding environments, yield potential can be significantly reduced when using wider rows due to the inability of the plant canopy to completely cover the ground area and efficiently utilize available net solar radiation (Myers and Foale, 1981; Holland and McNamara, 1982). Though Wortmann et al., (2007) and Varvel and Wilhelm (2003) reported yield response of grain sorghum to increased $\mathrm{N}$ rate, the relatively low response to $\mathrm{N}$ rate observed in 2006 may be attributed to the overall low in-season precipitation $(82 \%$ of long term average) and the higher climatic deficit $(-313 \mathrm{~mm})$ at vegetative and half bloom stages.

Kamoshita et al., (1998), reported that increased N application resulted in increased grain $\mathrm{N}$ concentration in grain sorghum. Similar observation have been made with $\mathrm{N}$ concentration in grassland yield and maize (Ortega et al., 2016; Chen et al., 2015). As N rate increased, the amount of $\mathrm{N}$ translocated from biomass to grain increased in both 2006 and 2007. The amount of $\mathrm{N}$ translocated from biomass to grain in 2006 ranged between $29 \%$ for no $\mathrm{N}$ application and $35 \%$ for high $\mathrm{N}$ application compared to $46 \%$ for no $\mathrm{N}$ and $51 \% \mathrm{~N}$ for high $\mathrm{N}$ application translocated to the grain in 2007. According to Hirel et al., (2007), after flowering, the amount of $\mathrm{N}$ accumulated in the plant biomass is remobilized and translocated to the grain.
According to Dobermann (2005), $\mathrm{PFP}_{\mathrm{N}}$ is the most useful component of NUE to farmers because it integrates the use efficiency of both indigenous and applied $\mathrm{N}$ resources. Other studies with grain sorghum found similar reductions in NUE components with increased $\mathrm{N}$ rate (Wortmann et al., 2007; Buah et al., 1998). Lower NUE with skip-row is related to reduced yield, likely due to the lack of full canopy cover with skip-row configurations, limiting the ability of the crop to fully utilize solar energy for photosynthetic processes. Since water stress was not observed in this study, differences in NUE can be attributed to under-utilization of $\mathrm{N}$ and other resources such as solar radiation. According to Cechin (2004), water stress in sorghum will reduce $\mathrm{N}$ concentration, stomatal conductance, transpiration and photosynthetic rate compared with well watered plants. Sorghum cultivar and management differences can also affect NUE (Gardner et al., 1994; Sow et al., 1998).

\section{Conclusions}

Rainfall is normally adequate in South-Central Nebraska such that $\mathrm{s} 0$ yields are likely to be higher than $\mathrm{s} 1$ and s2 yields. Grain sorghum yield, $\mathrm{N}$ concentration and $\mathrm{N}$ uptake were affected by $\mathrm{N}$ rates. Grain yield response to N rate for each RPA was quadratic in 2006 and 2007 with very high coefficients of determination. With each RPA, the addition of $50 \mathrm{~kg} \mathrm{ha}^{-1} \mathrm{~N}$ increased NUE but raising the rate to 100 or $150 \mathrm{~kg} \mathrm{ha}^{-1} \mathrm{~N}$ resulted in significant reduction in NUE. Addition of $150 \mathrm{~kg} \mathrm{ha}^{-1} \mathrm{~N}$ with $\mathrm{s} 0$ and $100 \mathrm{~kg} \mathrm{ha}^{-1} \mathrm{~N}$ with skip-row planting gave the highest grain yield to $\mathrm{N}$ application in both years.

Conflict of interest

The authors declare that there are no conflicts of interest. 


\section{Acknowledgement}

We acknowledge research technical assistance provided by Mark Strnad and Glen Slater. This study was conducted with partial financial support provided by U.S. Agency for International Development to the International Sorghum and Millet Collaborative Research Support Program under the terms of Grant no. LAG-G-00-96-900009-00 and partial financial support from Scholarship Secretariat, Government of Republic of Ghana.

\section{References}

Abunyewa, A.A., Ferguson, R.B., Wortmann, C.S., Lyon, D.J., Mason, S.C., Irmak, S., Klein, R.N. 2011. Grain sorghum water use with skip-row configuration in the Central Great Plains of the USA. African J. Agric. Res. 6, 5328-5338.

Abunyewa, A.A., Ferguson, R.B., Wortmann, C.S., Lyon, D.J., Mason, S.C., Klein, R.N. 2010. SkipRow and Plant Population Effects on Sorghum Grain Yield. Agron. J. 102, 296-302.

Baligar, V.C., Fageria, N.K., He, Z.L. 2001. Nutrient use efficiency in plants. Comm. Soil Sci. Plant Anal. 32, 925-950.

Borrell, A.K., Hammer, G.L. 2000. Nitrogen dynamics and physiological basis of stay-green in sorghum. Crop Sci. 40, 1295-1307.

Bray, R.H., Kurtz, L.T. 1945. Determination of total organic and available forms of phosphorus in soil. Soil Sci. 599, $39-45$.

Buah, S.S.J., Maranville, J.W., Traore, A., BramelCox, P. 1998. Response of nitrogen use efficient sorghum to nitrogen fertilizer. J. Plant Nutr. 21, 2303-2318.
Cassman, K.G., Dobermann, A., Walters, D.T. 2002. Agroecosystems, nitrogen-use efficiency, and nitrogen management. Royal Swedish Aca. Sci. Ambio. 31, 132-140.

Cechin, I. 2004. Photosynthesis and chlorophyll fluorescence in two hybrids of sorghum under different nitrogen and water regimes. Photosynthetica. $35,233-240$.

Chen, Y., Xiao, C., Wu, D., Xia, T., Chen, Q., Chen, F., Yuan, L., Mi, G. 2015. Effects of nitrogen application rate on grain yield and grain nitrogen concentration in two maize hybrids with contrasting nitrogen remobilization efficiency. European J. Agron. 62, 79 - 89.

Dobermann, A. 2005. Nitrogen use efficiency - state of the art. Paper presented at the IFA International Workshop on Enhanced-Efficiency Fertilizers. Frankfurt, Germany, 28-30 June, 2005.

Gardner, J.C., Maranville, J.W., Paparozzi, E.T. 1994. Nitrogen use efficiency among diverse sorghum cultivars. Crop Sci. 34, 728-733.

Henriksen, A., Selmer-Olsen, A.R. 1970. Automatic methods for determining nitrate and nitrite in water and soil extracts. Analyst. 95, 514-518.

Hirel, B., Gouis, J.L., Ney, B., Gallais, A. 2007. The challenge of improving nitrogen use efficiency in crop plants: towards a more central role for genetic variability and quantitative genetics within integrated approaches. J. Exptal. Bot. 58, 23692387.

Holland, J.F., McNamara, D.W. 1982. Weed control and row spacing in dryland sorghum in northern New South Wales. Aust. J. Exptal. Agric. Anl Husb. 22, 310-316.

Jackson, M.L. 1967. Soil Chemical Analysis. Prentice-Hall, New Delhi, India. 
Kamoshita, A., Fukai, S., Muchow, R. C., Cooper, M. 1998. Genotypic variation for grain yield and grain nitrogen concentration among sorghum hybrids under different levels of $\mathrm{N}$ fertilizer and water supply. Aust. J. Agric. Res. 49, 737-747.

Lindsay, W.L., Norvel, W.A. 1978. Development of DTPA soil test for zinc, iron, manganese and copper. Soil Sci. Soc. Amer. J. 42, 421-428.

Mosier, A.R., Syers, J.K., Freney, J.R. 2004. Agriculture and the nitrogen cycle. Assessing the Impacts of Fertilizer Use on Food Production and the Environment. Scope-65. Island Press, London.

Myers, R.J.K., Foale, M.A. 1981. Row spacing and population density in grain sorghum - a simple analysis. Field Crops Res. 4, 146-154.

Nelson, DW., Sommers, L.E. 1982. Total carbon, organic carbon and organic matter.pp. 539-579. In: Page, A.L., Miller R.H., Keeny, D.R. (eds.). Methods of soil analysis. Part 2. Chemical and Microbiological Agronomy 9, (2nd eds). American Society of Agronomy, Madison, USA.

Olufayo A., Baldy, C., Ruelle, P. 1996. Sorghum yield, water use and canopy temperatures under different levels of irrigation. Agric. Water Manag. 30, 77-90.

Ortega, L., Alfaro, M., Martinez-Lagos, J. 2016. Soil nitrogen contribution to grasslands yield in southern Chile its implications for nitrogen use efficiency nitrogen use efficiency. J. Soil Sci. Plant Nutr. 16, 310-322.

Routley, R., Broad, I., McLean, G., Whish, J., Hammer, G. 2003. The effect of row configuration on yield reliability in grain sorghum: 1 . yield, water use efficiency and soil water extraction. Proc. 11th Australian Agronomy Conference, Geelong, Victoria. 2-6 Feb. 2003. Available at http://www. regional.org.au/au/asa/2003/c/9/routley.htm Date accessed July 6, 2015. Australian Society of Agronomy, Gosford, Australia.
Routley, R., Lynch, B., Conway, M. 2006. The effect of sorghum row spacing on fallow cover distribution and soil water accumulation in central Queensland. Proceedings of 3th Agronomy Conference 2006. 10-14 September 2006, Perth, Western Australia. Date accessed July 6, 2015. Australian Society of Agronomy, Gosford, Australia.

Schlegel, A. J., Grant, A.C., Havlin, J.L. 2005. Challenging approaches to nitrogen fertilizer recommendations in continuous cropping systems in the Great Plains. Agron. J. 97, 391-398.

Shackel, K.A., Hall, A.E. 1984. Effect of intercropping on the water relations of sorghum and cowpea. Field Crops Res. 8, 381-387.

Shapiro, C.S., Ferguson, R.B., Hergert, G.W., Wortmann, C.S., Walters, D.T. 2009. Fertilizer suggestions for corn. University of Nebraska-Lincoln Extension EC117.

Sow, A.A., Hossner, L.R. Unger, P.W., Stewart, B.A. 1998. Effect of cultural practices on nitrate in the soil and nitrogen in the grain sorghum. Comm. Soil Sci. Plant Anal. 29, 612-623.

Stewart, B.A., Steiner, J.L. 1990. Water-use efficiency. In Singh, R.P., J.F. Farrnce and B.A.Stewart (ed.). Advances in Soil Science. Springer-Verlag, New York. p 151-173.

Stone, L.R., Schlegel, H.A., Gwin, Jr. R.E., Khan, A.H. 1996. Response of corn, grain sorghum, and sun half bloom to irrigation in the high plains of Kansas. Agric. Water Manag. 30, 251-259.

Varvel, G.E., Wilhelm, W.W. 2003. Soybean nitrogen contribution to corn and sorghum in western Corn Belt rotations. Agron. J. 95, 1220-1225.

Wortmann, C.S., Mamo, M., Dobermann, A. 2007. Nitrogen response to grain sorghum in rotation with soybean. Agron. J. 99, 808-813. 